\title{
Interview with Dunja Fehimović and Rebecca Ogden
}

The two iconic covers of the magazine The Economist showing the images of Christ the Redeemer, a symbol for Brazil, taking off (Prideaux, 2009) and crashing into Corcovado (The Economist, 2013) illustrate how complex socioeconomic and political developments in one country can quickly become condensed and simplified as they circulate in the international media. This is one example of how simple ideas can become 'brand-like' and attach themselves to the perceptions of nations in both their symbolic overdetermination and the tenacity with which they stick to the countries in question.

The idea that the reputations of countries can be compared to brands has become increasingly popular in researches that apply a marketing approach to understanding nations and politics, with dozens of new studies attempting to measure the foreign perceptions of those countries and as many projects attempting to manage the so-called nation brand (Aronczyk, 2013; Roth and Diamantopoulos, 2009)

In Branding Latin America: Strategies, Aims, Resistance Dunja Fehimović (Lecturer in Hispanic Studies at the Newcastle University) and Rebecca Ogden (Lecturer in Latin American Studies at the University of Kent) examine how perceptions of national image and reputation are shaped in the continent and take a more critical approach in its focus on the ways that branding perpetuates and even exacerbates inequalities and injustices. They define branding as the practice of molding image for profit-driven motives and argue that it is often seen as a means to successfully intervene in this enduringly uneven global system (Fehimović and Ogden, 2018).

In this interview, conducted with both organizers of the book via email in 2018, they discuss how the way Latin America has experienced global visibility and competitiveness since colonial times and argue that the production of an uneven playing field in the world makes the continent an interesting case of analysis in terms of branding. While the countries in the region are still perceived as peripheral, branding strategies have been seen as a means to intervene in the global system to retell national storylines or shed unfavorable ones --with uneven results in each of the countries that have attempted it.

Question - Nation branding has being a very popular topic of governments agenda in the past decades. How different you think is the case for that in Latin America in comparison to other places of the world? 
Dunja Fehimović and Rebecca Ogden - As the introduction to Branding Latin America argues, Latin America is an interesting context in which to consider branding --the practice of moulding image for profit-driven motives - because of the way that the region has experienced global visibility and competitiveness. That specific experience begins with colonization and the birth of global capitalism. The conquest of the Americas was the decisive moment in the production of an 'uneven playing field', in which it was the peripheral site of labour and production, while Europe was the centre. Global capitalism in the 20th and 21st centuries has continued to construct the world as a market and in so doing, reinforce historical structural and symbolic inequalities. As a result, the national economies of many countries in the region have been geared towards becoming 'winners' in that global market, achieving development and overcoming dependence --efforts which have been further hampered by the import substitution industrialisation programmes in the 1980s, and resultant foreign debt, rocketing interest rates and hyperinflation. Neoliberal reform, implemented through privatisations and heavy budget cuts, targeted these issues but deepened inequalities and often worsened the crisis. In several Latin American countries neoliberal reform has been implemented during painful transitions from dictatorship to democracy, where attempts to understand and account for the past have been counterpointed by governments' desire to project a new, confident image to the world.

Branding is therefore often seen as a means to successfully intervene in this enduringly uneven global system, and to retell national storylines or shed unfavourable ones. In the globalized age of digital technologies, 24-hour media, and dependence on international markets, Latin American nations can strategically manipulate and articulate their reputations to global others, as both recognizable equals and distinct competitors. These efforts are also directed towards the population, as they articulate a coherent narrative of national, collective self-imagining.

Question: The aspiration to be recognised and admired in the rest of the world has always been a part of the national identity of Brazil (Ricupero, 2017). Since the nineteenth century, the Brazilian government has tried to project an image of a "modern" "Western" country. Do you think there's any connection between that and the more recent idea of "branding"? Is that something that is specific of the history of Brazil, or is it common in the rest of the region as well?

Fehimović and Ogden: In some ways, nation branding does appear to represent the latest chapter in a longer story that also features nineteenth century nation building. It 
can be convincingly argued that the nation brand is the inevitable extension of the national flag or anthem, in that it serves to forge internal coherence and promote international visibility. As you point out, that national image has often revolved around the idea of being modern. The first contributor to the book, Andrea Paz Cerda Pereira, highlights aspirations to modernity in Chile's participation in World Expos from 1851 to 2010; in her analysis, 19th century world fairs are precursors to the marketization of national imaginaries that came later. In addition, certain outcomes of branding do certainly recall global dynamics of the nineteenth century. In their bids to intensify and direct global flows of goods, people, and capital, branding initiatives create and entrench internal socio-spatial divisions of labor as well as 'fixing' certain Latin American countries as sources of raw materials or as sources of cheap, skilled labor. In this process, the divisions of labor carved out by the extractivism and forced mass migrations characteristic of the colonial period are reproduced and reconfigured for a new era.

Despite these continuities, the case studies in this book show that nation branding represents a distinct, new phenomenon with unique aims and practices. The project of forging national unity and international visibility now has one ultimate aim: economic profit and competitiveness in an ever-more intricately interconnected global marketplace. That competitiveness and recognition is sought not just in dialogue with a world of other 'modern' or so-aspiring nations, but also from a world of corporations whose investment carries the potential to influence the country's economic fate.

Question: Although branding is normally related with the projection of a positive image abroad, Brazil has been going to a very deep crisis, and the worst recorded recession. There is a short discussion in the book about the "década perdida" in Argentina. Do you think the case of Brazil can be thought in line with that? Will these years be "branded" as Brazil's lost time?

Fehimović and Ogden: The notion of the brand is inherently slippery and its functioning therefore necessarily insidious, but it is generally used in order to signal and enhance competitiveness. In that sense, of course, the 'década perdida' in Argentina and any equivalent in Brazil would constitute the opposite of branding, suggesting instead a kind of lapse in competitiveness that spreads out from the economic into other spheres. On the other hand, in its (English) etymology, 'branding' also carries the traces of the violence by recalling painful marks of possession or categorisation. It may be in this latter sense that the idea of Argentina's 'lost decade' 
could be understood: as an undesirable mark that tarnishes the country's image internationally, but also externalises some of the pain that the crisis entailed for its citizens.

The possibility of thinking about recent developments in Brazil's economic and political landscape in terms of such phrases recalls the striking front covers of The Economist Magazine, which announced in 2009 that Brazil was 'taking off', but four years later, asked whether the country had now 'blown it'. The striking images of Christ the Redeemer launching off and crashing into Corcovado illustrate how complex socioeconomic and political developments quickly become condensed and simplified as they circulate in the international media, becoming almost 'brand-like' in both their symbolic overdetermination and the tenacity with which they stick to the countries in question.

The development of catchphrases or denominations like 'the lost decade' tends to require a geographical or historical distance from which to distill overarching narratives or simplified images. The uncertainty of Brazil's continuously shifting situation makes such generalisation difficult. What is certain is that the outcome of the October elections will prove decisive in shaping the internal narrative and international image of the country's recent past.

Question: A recent article in The Guardian discussed the idea of 'branding' for places and appeared to show that it was a popular trend in areas less known to the western world --such as eastern Europe and Latin America (Subramanian, 2017). In the book you talk about how branding is used as a means for "third world" countries to try to be seen as "equal" to Western powers. Could branding be thought as a tool to make countries all alike? What is the danger of that?

Fehimović and Ogden: Some defenders of branding have claimed that the practice may allow historically peripheral countries to change the global order in their favor, through the articulation of competitive identities, by attracting foreign investment, tourism and strengthening forms of public diplomacy. They even claim that branding can create a new, 'fairer' world. Our book takes a rather more critical approach in its focus on the ways that branding perpetuates and even exacerbates inequalities and injustices. For instance, Félix Lossio Chávez's contribution shows that a Peruvian tourism brand strategy does not simply create new narratives, but suppresses other less favorable ones and even distracts from exploitative and unequal political practices in Peru. Whether or not branding can create the conditions for a new fairer world, we 
feel that it does offer a way to reconsider world systems theory; aside from how valid or not its classifications of center/periphery, developed/underdeveloped now are, and in recognition of the fact that these narratives fallen out of favor in many academic circles, we are interested in how they are nonetheless invoked, reinforced, resisted, or reconfigured by practices and discourses of branding.

The second part of your question raises an interesting point: one paradox of branding initiatives is that they aim to simultaneously re-cast historically marginalised countries as equals, yet also seek to carve out difference in the form of marketability. In affirming the 'local' and the 'national' as unique containers of meaning and value, contemporary branding practices appear to counteract the flattening of differences associated with globalization and neoliberalism. However, by reinforcing the exchange value of the local, it is also complicit in the erosion of that very difference.

Question: The book brings forward a very interesting critique of branding in terms of nation, but does not focus much on the ideas of international images of these nations, which is an important part of what "place branding" analyses. Do you agree with the idea that nations (and places) have international images? if so, is there any importance for that apart from the logic of the market (neoliberalism)? Is there an alternative to following this neoliberal recipe for recognition in the West?

Fehimović and Ogden: Of course, international reputation is a very important factor in branding, not least as its justification. Consulting agencies and professionals start with the assumption that a nation's image already exists 'out there', formed over decades, if not centuries, from the sediment of cliches and stereotypes. By failing to actively remould this image, branding experts argue, nations, cities, or regions effectively agree to pay the price for the negative associations, indifference, or ignorance of others. There are also publications, agencies, and professionals dedicated to ranking countries' reputations, turning what are often perceived in day-to-day life as qualitative impressions or assumptions into quantitative data that can be used to design initiatives and campaigns with specific aims, usually oriented towards economic development.

Nobody has hit on a perfect formula to summarise, quantify or explain a country's international reputation. That is not to say that an international image is entirely imaginary or intangible, however. In addition to the effects that reputation may have on the political and economic sphere via trade agreements and investment schemes, for example, its effects can also become all too tangible at the micro-level of 
citizens' lives. In Paula Gómez Carrillo's chapter, one-to-one interviews reveal how the ignorance and prejudice inherent in many foreigners' perception of Colombia as a lawless land of drug trafficking not only manifest themselves in everyday interactions - at the airport, for example - but can also potentially affect an individual's prospects of employment and success. 'It's Colombia NOT Columbia' is a coordinated campaign that functions through grassroots involvement and social media to increase the country's visibility and correct misconceptions, but as Gómez Carrillo's analysis so astutely reveals, it also enforces a new kind of discipline on the citizen, who becomes an entrepreneurial subject tasked with the responsibility of rebranding both themselves and their country. The individual experience and struggle thus reinforces a neoliberal system based on the principle of competition.

Question: Apart from organizing the book, both of you analyzed "branding" in Cuba. how do you think this year's change of government plays into the brand the country is projecting? Has Cuba been adapting its political reality in order to change its image? Is this new government an attempt to renew the "brand" of the country?

Fehimović and Ogden: The question of 'branding' is rather complicated in the case of Cuba, as we both point out in the book: the political uniqueness that contributes to the island's exotic appeal in the tourism sector, for example, also prevents the country from appropriating practices or discourses of branding - and the neoliberal logic on which they are based - in any overt way. This comes across in Rebecca Ogden's chapter about the tourism campaign, 'Auténtica Cuba', and its very deliberate choices about what to include and leave out of the country's brand. Of course, it could be argued that an awareness of Cuba's exceptional political system and the iconography of the Revolution is so widespread that it permeates all other images of the country, but the Revolution has - so far - been deliberately left out of Cuba's official branding initiatives.

The recent election of Miguel Díaz Canel as Cuba's president may have surprised those unfamiliar with the details of the island's political system: not only was this a demonstration of Cuba's complex, multi-layered electoral system (in March this year, the process started with elections for neighbourhood representatives, then municipal elections, and finally elections for the members of the National Assembly, before a vote to nominate the candidate for presidency) but it also showed a significant symbolic shift away from the leadership of the Castros and the guerrilla generation they represented. Díaz Canel's roles over the years - as Minister of Higher Education, 
Vice President of the Council of Ministers, and, most recently, First Vice President mean that his election is hardly surprising. However, it does problematise the international image of Cuba as governed by a Castro dynasty, and shows a significant transfer of power to generations of Cubans who, like Díaz Canel, were born within the Revolution. Nevertheless, we would be hard pressed to see this as an attempt to 'rebrand' the country; Díaz Canel is likely to continue with Raúl Castro's 'slow but steady' economic reforms, whose primary aim is to address long-standing issues such as the dual-currency economy or housing, rather than to strategically alter the country's international image.

References:

Aronczyk, Melissa. 2013. Branding the nation: the global business of national identity. Oxford; New York: Oxford University Press.

Fehimović, Dunja, and Rebecca Ogden. 2018. Branding Latin America: Strategies, Aims, Resistance. London: Lexington Books.

"Has Brazil blown it? - Brazil's future". [s.d.]. Accessed 27 august de 2018. https://www.economist.com/leaders/2013/09/27/has-brazil-blown-it.

Prideaux, John. 2009. "Getting it together at last: A special report on business and finance in Brazil". The Economist 14: 2-16.

Ricupero, Rubens. 2017. A Diplomacia na Construção do Brasil 1750-2016. São Paulo: Versal

Roth, Katharina P., e Adamantios Diamantopoulos. 2009. "Advancing the Country Image Construct". Journal of Business Research 62 (7): 726-40. https://doi.org/10.1016/j.jbusres.2008.05.014.

Subramanian, Samanth. 2017. "How to sell a country: the booming business of nation branding". The Guardian, 7 de novembro de 2017. https:/www.theguardian.com/news/2017/nov/07/nation-branding-industry-how-tosell-a-country. 